\title{
Temporal changes in macrofauna as response indicator to potential human pressures on sandy beaches
}

\author{
Filipa Bessa ${ }^{\mathrm{a}, *}$, Sílvia C. Gonçalves ${ }^{\mathrm{a}, \mathrm{b}}$, João N. Franco ${ }^{\mathrm{c}}$, José N. André ${ }^{\mathrm{d}}$, \\ Pedro P. Cunha ${ }^{\mathrm{e}}$, João Carlos Marques ${ }^{\mathrm{a}}$ \\ a IMAR-CMA - Marine and Environmental Research Centre, Department of Life Sciences, University of Coimbra, 3004-517 Coimbra, Portugal \\ ${ }^{\mathrm{b}}$ School of Tourism and Maritime Technology, Marine Resources Research Group - GIRM, Polytechnic Institute of Leiria, Campus 4, Santuário Na. Sra. dos \\ Remédios, 2520-641 Peniche, Portugal \\ ${ }^{c}$ CIIMAR, Centre of Marine and Environmental Research, Rua dos Bragas 289, 4050-123 Porto, Portugal \\ d Department of Geography, University of Coimbra, 3004-517 Coimbra, Portugal \\ e IMAR-CMA - Marine and Environmental Research Centre, Department of Earth Sciences, University of Coimbra, 3004-517 Coimbra, Portugal
}

\section{A R T I C L E I N F O}

\section{Article history:}

Received 1 November 2013

Received in revised form 11 January 2014

Accepted 14 January 2014

\section{Keywords:}

Sandy beaches

Macrofaunal assemblages

Temporal changes

Crustaceans

Human pressures

Coastal tourism

\begin{abstract}
A B S T R A C T
Sandy beaches are natural dynamic ecosystems, which are becoming worldwide increasingly disturbed by intensive human direct use, coastal development and erosive evolution. In this study, we have examined whether ten years of potential increased human pressures have resulted in significant changes in the macrofaunal assemblages' structure and composition of two mesotidal sandy beaches (Cabedelo urban beach, and Quiaios - rural beach) on the European Atlantic coast (Portugal). Seasonal macrofauna collections were performed at both beaches in two different periods, one in 1999-2000 and another in 2010-2011. The physical variables did not change significantly in both beaches throughout the studied periods, however, the urban beach was subject to an increase of human pressures (tourism and shoreline modifications) over the 10 -years interval considered when compared with the rural beach. The univariate community descriptors (total density, species richness and diversity) did not differ significantly among periods for the rural beach. In contrast, temporal differences were found at the most urbanised beach, principally regarding the abundances of the amphipod Talitrus saltator and the isopod Tylos europaeus, two of the most abundant species at both beaches. PERMANOVA tests enhanced these temporal variations and the SIMPER analysis attributed to these species the main differences found between periods in this beach. Since the physical environment was similar in both periods, the ecological changes were most likely attributed to the increased human pressures observed at the urban beach. Nevertheless, this study highlights the need of further robust and effective impact assessments and long-term studies to better discern between natural and human induced changes on sandy beaches.
\end{abstract}

(c) 2014 Elsevier Ltd. All rights reserved.

\section{Introduction}

Human activities have been recognised to place heavy pressures on coastal ecosystems as the growth in both economies and populations continues (Halpern et al., 2008; Millenium Ecosystem Assessment, 2005). Exposed sandy beaches are not an exception and during the last decades, these ecosystems have been subjected to severe and increasing pressures in most countries, as a result of conflicting uses such as coastal development, environmental pollution, and intensive tourism, among other coastal disturbances (review in Defeo et al., 2009) as those documented in the

\footnotetext{
* Corresponding author. Tel.: +351239836 386.

E-mail address: afbessa@uc.pt (F. Bessa).
}

Portuguese coast (Veloso-Gomes and Taveira-Pinto, 2003; Coelho et al., 2009).

In addition, on urbanised coasts (sensu Veloso et al., 2006), management practices such as nourishment and coastal armouring have been intensively used to counteract the erosive evolution of coasts, but the ecological implications of these actions are less considered (Defeo et al., 2009; Schlacher et al., 2006). Superimposed on these trends of coastal impacts is the predicted increase in the frequency and intensity of extreme natural phenomena (e.g. storms) due to the effects of global climate change that can dramatically affect the fauna and flora of ocean-exposed sandy beaches (Brown and McLachlan, 2002; Defeo et al., 2009; Dugan et al., 2010; Schlacher et al., 2007, 2008b).

Exposed sandy beaches are physically dynamic habitats where diverse assemblages of macroinvertebrates can occur (McLachlan and Brown, 2006), and since they are known to be structured mainly by physical factors (reviewed in Defeo and McLachlan, 2005), 
documenting the biotic responses to particular modifications of the physical environment can be used for the assessment of the ecological conditions of beaches. To this regard, over the last years, several studies have been showing the negative effects to macrofaunal communities and/or individual species on beach-aeolian dune environments, when facing particular human disturbances caused by coastal management practices such as beach nourishment projects (e.g. Bessa et al., 2013; Fanini et al., 2009; Jones et al., 2008; Schlacher et al., 2012) and coastal armouring (Dugan and Hubbard, 2006; Dugan et al., 2008; Walker et al., 2008). Still, human recreational activities have been recognised to negatively affect beach fauna due to the intensive use of beaches (Schlacher and Thompson, 2012; Schlacher et al., 2011; Ugolini et al., 2008; Veloso et al., 2008) and to the impact of off-road vehicles (e.g. Schlacher et al., 2008a; Sheppard et al., 2009; Schlacher and Lucrezi, 2010; Walker and Schlacher, 2011).

Despite the long history of human activities on sandy beaches, little is known about their potential ecological implications over the course of time. When addressing this issue, the main difficulty for sandy beach ecologists is the fact that apart from the adverse effects of human activities, exposed sandy beaches show wide variations in the environmental conditions making it difficult to discern natural from human-induced changes. In addition, and regarding the European Atlantic coast, the knowledge about the ecological conditions of beaches before the increase of the above-mentioned human pressures is still scarce.

For instance, the mainland Atlantic coast of Portugal extends along more than $900 \mathrm{~km}$, of which $60 \%$ are beaches and according to the last official European reports (Eurosion, 2004; GHK, 2006), $28 \%$ of this coast is facing severe problems of erosion. Over the last decades, in order to counteract the erosion process and the "coastal squeeze" phenomenon of this coastline, coastal management practices (in particular beach nourishment and breakwaters) have been applied on the mainland coast of Portugal (VelosoGomes and Taveira-Pinto, 2003), and were already proposed in the Plan of the Portuguese Environment Agency (PAPVL) for the period of 2012-2015.

On the other hand, the increase in the number of tourists recorded in the country (INE - National Institute of Statistics) in the last years has potentiated the improvement of sandy beaches' facilities to promote the aesthetic and economic value of beaches along the entire coast (Veloso-Gomes and Taveira-Pinto, 2003). However, the ecological implications of these actions were never assessed.

In 1999-2000, Gonçalves et al. (2009) identified three supralittoral crustaceans as key elements at two similar exposed sandy beaches in the central coast of Portugal and Gonçalves et al. (2013) proposed the use of the bioecology of these species as potential assessment tools to evaluate environmental disturbances.

Given the vital role of macroinvertebrates in the ecological functioning of sandy beaches the goals of this study were: (1) to investigate possible temporal variations in the structure and composition of the macrofaunal assemblages on two sandy beaches during two periods (1999-2000 and 2010-2011), and (2) to assess whether possible ecological changes reflect the effects of long-term human pressures. This assessment should be seen as a first step towards more comprehensive and robust evaluation of potential cumulative human pressures and their impact on sandy beaches.

\section{Materials and methods}

\subsection{Study area}

This study was conducted at two exposed sandy beaches, Cabedelo and Quiaios, in central Portugal, on the western coast of the Iberian Peninsula (Fig. 1). This coastal area presents a warm temperate Atlantic-Mediterranean climate and semidiurnal tides with maximum amplitude of about $3.5 \mathrm{~m}$ (Gonçalves et al., 2009). These beaches are affected by a wave regime that has an average significant wave height of $1.8 \mathrm{~m}$ (with wave directions of $242-297^{\circ}$ $\mathrm{N}$ ), reaching $5.0-6.5 \mathrm{~m}$ ( $1 \%$ of the total, with $\mathrm{N} 262-282^{\circ}$ directions) (Santos et al., 1991). The Cabedelo sandy beach is located in the vicinity of the Mondego estuary, while the Quiaios beach is located further north, about $8 \mathrm{~km}$ north from Cape Mondego (Fig. 1).

Regarding the morphodynamic state, both exposed beaches are of high-energy intermediate type, and present relatively similar conditions of exposure to wave actions: according to the rating scheme for assessing the degree of exposure in sandy beaches (McLachlan, 1980), Quiaios is classified as a very exposed beach (exposure rate: 16) and Cabedelo as exposed beach (exposure rate: 15). In addition, the littoral dynamics of this coastal sector and the historic beach evolution is provided by Cunha and Dinis (1998, 2002).

Cabedelo beach is widely recognised as an urban beach since it is closer to the important tourist centre town of Figueira da Foz, and have a high potential for recreational use. In this sense, in order to improve the human use of beaches, the entire urban area has been subjected to diverse transformation actions along time, i.e. improvement of touristic facilities and beach grooming (the removal of organic beach-cast material along the strandline that occurs in particular during the spring-summer seasons), and consequently leading to an increase of human use of the beach (e.g. recreational activities such as surf championships, in situ observations). The aeolian dunes immediately adjacent to this beach are also backed by infrastructures (boardwalks and parking areas, see Fig. 1b).

In addition, the coastal zone management plans approved for the entire coast of mainland Portugal to counteract the erosive evolution (Veloso-Gomes and Taveira-Pinto, 2003), has been also implemented for the Cabedelo beach, in particular, the extension of a breakwater $(400 \mathrm{~m})$ and related adjustment with rocks on the beach (in 2008 and 2010, source: local authorities). In contrast, at Quiaios beach, which is located in a rural area, the sampling point was chosen on an undisturbed zone, with limited access (no physical facilities placed on this zone on the beach, see Fig. 1a) and for this reason have a lower human beach use. This beach is about $3 \mathrm{~km}$ wide and rises to nearly $100 \mathrm{~m}$ and is backed by an extensive and well-developed dune sheet with varied vegetation and biota (more details in Gonçalves et al., 2009).

In the last years, the entire coast of mainland Portugal has received an increase in the touristic occupation, especially during the warmer spring and summer months (information provided by the national authorities of tourism - INE and Tourism of Portugal), in particular for the urban (city of Figueira da Foz) and rural (Quiaios) areas (Fig. 2). This data was used to obtain a quantification (a proxy) of the potential increase in the human use of these sandy beaches over the studied periods.

\subsection{Sampling design}

Between 1999 and 2000, Gonçalves et al. (2009) analysed the macrofaunal communities' structure at Quiaios and Cabedelo beaches. Quantitative samples were taken monthly, during low neap tides by using a wooden square of $0.25 \mathrm{~m}^{2}$ to a depth of $20 \mathrm{~cm}$ and were sieved through a $1 \mathrm{~mm}$ mesh. The sampling design comprised 2 transects arranged at regular intervals (10 levels, 3 replicates per level) between the low-water mark and the foredune. For each transect, the first five sampling levels from the waterline to the high low tide watermark were considered the intertidal zone and the subsequent five levels until the base of the dunes, the supralittoral zone. The animals collected were separated in the laboratory and preserved in $70 \%$ alcohol for identification. Sediment samples were collected to determine the sediment grain 


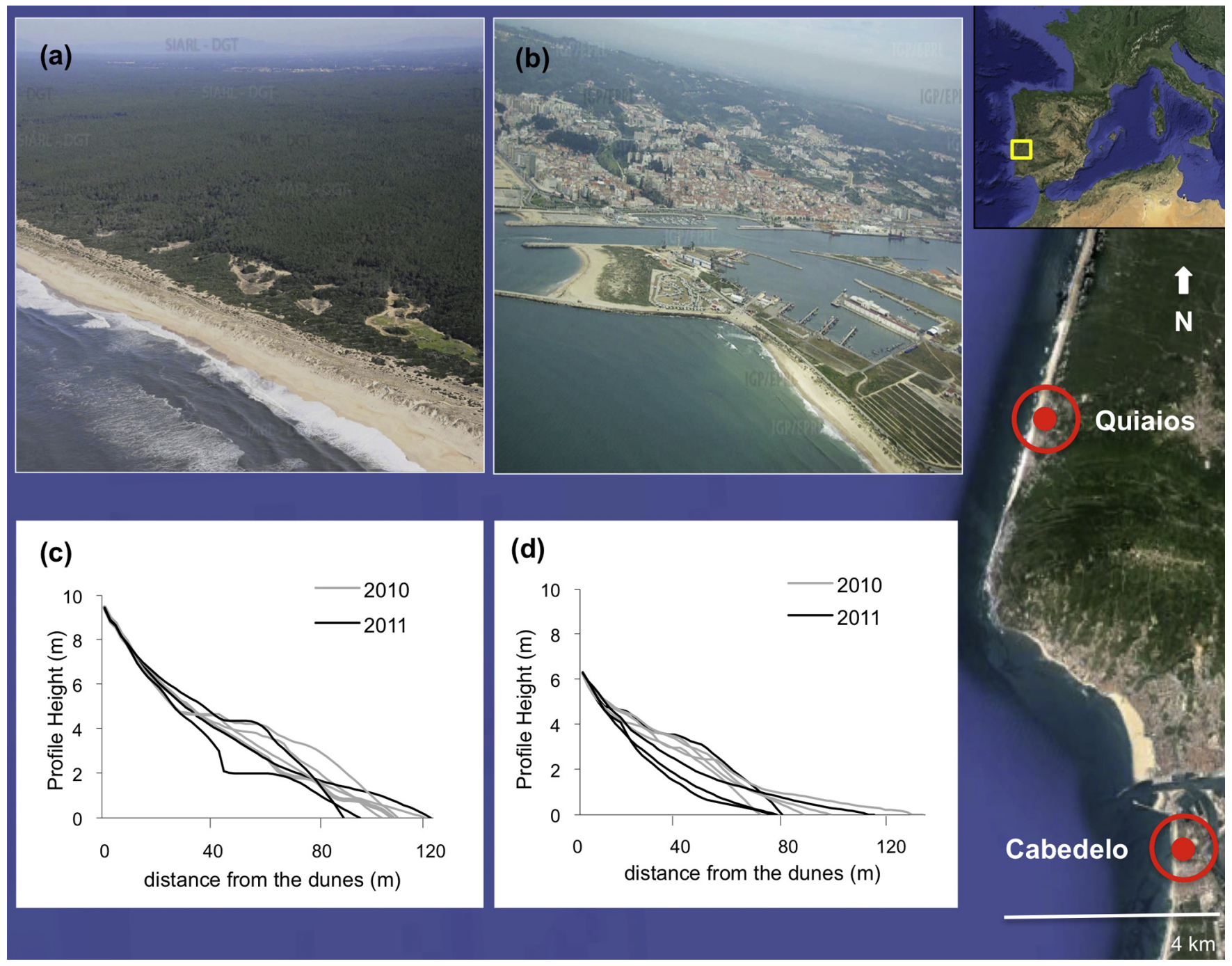


transversal topographic profiles (c) for Quiaios and (d) for Cabedelo drawn in 2010-2011. Aerial photos provided by SIARL.

size, water content in the sediment and organic content in the sediment following the protocol described in Marques et al. (2003).

During 2010 and 2011, Cabedelo and Quiaios beaches were sampled once on each season (January for winter, May for spring, August for summer and November for autumn), comprising a total of eight sampling events. The sampling design and beach surveys followed standard techniques described in Gonçalves et al. (2009). Topographic transverse profiles of both beaches were obtained from a fixed point in the foredune to the swash zone at every sampling occasion.

\subsection{Data analyses}

For each period (1999-2000 and 2010-2011) species abundance data are expressed as ind $\mathrm{m}^{2}$. The 1999-2000 data were used for a qualitative comparison of the community structure and composition with the recent period in 2010-2011. The physical features (sediment properties, beach width) of the beaches were compared using paired- $t$ tests.

The potential impact on the macrofaunal assemblages from the increased human pressures were assessed using Before-After Control-Impact (BACI) design as outlined in Underwood (1992, 1993), contrasting data from the "impact" location (Cabedelo beach) with a "control" location (Quiaios beach). The two time periods were considered as "Before" (1999-2000) and "After" (2010-2011).

The biological data from the BACI design were analysed with Permutational Analysis of Variance (PERMANOVA) (Anderson, 2001) with four factors: (1) Beach (fixed: Cabedelo and Quiaios), (2) Time (fixed; 1999-2000 and 2010-2011); (3) Zone of the beach (fixed and nested in beach factor, supralittoral and intertidal) and (4) Season (fixed: nested in zone and beach: spring, summer, autumn and winter). Under this approach, an impact is indicated by statistically significant Beach $\times$ Time interaction (i.e. temporal trajectories of Cabedelo and Quiaios from before and after the potential increase in human pressures) and pairwise tests were performed to discriminate the differences within the levels of each factor. The response variables chosen for univariate descriptors were: mean total density, species richness (number of taxa) and diversity (Shannon-Wiener's Index) and were fourth root transformed. Euclidean distance similarity matrices were used for univariate data based on 9999 permutations of residuals under a reduced model.

The same statistical framework (BACI and PERMANOVA) was used to analyse spatial and temporal patterns in multivariate macrofauna assemblages' structure and pairwise comparisons were performed whenever significant differences were detected among the interaction term or the main factors (Anderson, 2001). 
a)
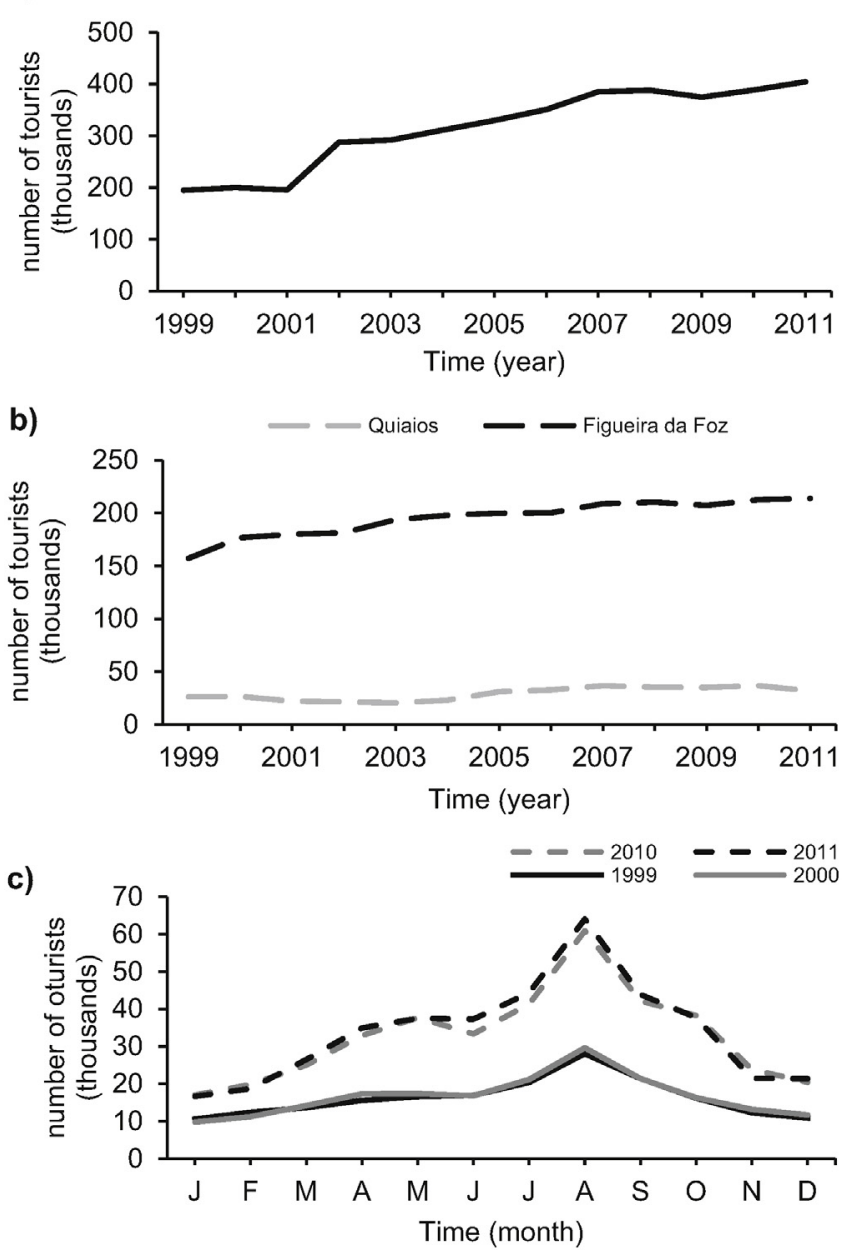

Fig. 2. Number of tourists from 1999 to 2011 (a) in the central region of Portugal, (b) at Quiaios and Figueira da Foz, and (c) distributed by month in the central region of Portugal (indicator: occupation rate, source: INE).

Based on fourth root transformed species abundance, data similarities were calculated using the Bray-Curtis coefficient. The statistical significance of variance components was tested using 9999 permutations (if the number of permutation was lower than 150 , the Monte Carlo permutation $p$ was used) and was set at a threshold of 0.05 . Differences in macrofaunal assemblages' structure were visualised using nonmetric multidimensional scaling ordinations of the average values from each Beach $\times$ Time interaction. When found significant differences in the PERMANOVA tests, the similarity percentage routine (SIMPER) was used to see which taxa contributed the most to the dissimilarities. All analyses were performed using the PRIMER v.6 with the PERMANOVA+ add-on (PRIMER-E Ltd., Plymouth, UK).

The potential relationships between the changes in the abundant species and the increase in the number of tourists were analysed using Pearson's correlations.

\section{Results}

\subsection{Habitat: what changed in 10 years?}

The specific beach physical environment was highly similar between the two periods (1999-2000 and 2010-2011) for both Cabedelo and Quiaios beaches (Table 1). The topographic transverse profiles drawn in 2010 and 2011 for both beaches revealed a stable shoreline slope with no clear differences between the years (Fig. 1c and d). In addition, the physical measurements (mean width and extension of the intertidal area) were highly similar between the periods at both beaches $(p>0.05)$, being Quiaios wider than Cabedelo (Table 1). Furthermore, paired $t$-tests applied to the overall physical variables on both beaches did not detect any significant temporal variations (Table 1). According to the Wentworth grain size scale (1922) the Quiaios beach had coarser sediments (mean grain size of $761.78 \mu \mathrm{m}$ in $1999-2000$ and $829.12 \mu \mathrm{m}$ in 2010-2011), while the Cabedelo beach had medium sands $(291.15 \mu \mathrm{m}$ in $1999-2000$ and $319.56 \mu \mathrm{m}$ in 2010-2011) in both periods (Table 1). Since the physical environment of those beaches did not change significantly between the first sampled period (1999-2000) and ten years after (2010-2011), special attention was given to the increased human pressures recorded between these periods, namely those related with tourism. The precise human beach use effect on the beach on both periods was not possible to assess (there is no available data on the number of tourists on the beach itself), in this sense we analysed the number of tourists staying in the central region of Portugal during the period of 1999 to 2011 (Fig. 2). During this 10-years interval there was a clear increase in the number of tourists in the central region of Portugal (Fig. 2a), with a higher number being recorded in the urban zone (Cabedelo) when compared with the rural area of Quiaios (Fig. 2c). A seasonal pattern was also recorded in both periods, with higher number of tourists being recorded during the spring-summer months (from May to September, Fig. 2c).

\subsection{Macrofaunal assemblages: what changed in 10 years?}

The taxonomic structure of the macrofauna recorded at Quiaios and Cabedelo beaches was similar over the studied period (1999-2000 and 2010-2011, Appendix A). In particular, the three most abundant taxa (adding up to $90 \%$ of the total abundance) were crustaceans, namely, the oniscoidean isopod Tylos europaeus and two talitrid amphipods, Talitrus saltator and Talorchestia brito. However, a different pattern of dominance of these species in the

Table 1

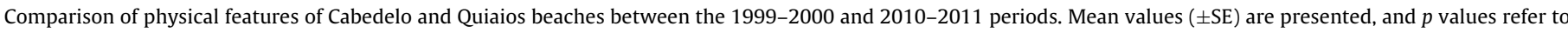
paired $t$-test between periods.

\begin{tabular}{|c|c|c|c|c|c|c|}
\hline \multirow[t]{2}{*}{ Feature } & \multicolumn{3}{|l|}{ Cabedelo } & \multicolumn{3}{|l|}{ Quiaios } \\
\hline & 1999-2000 & 2010-2011 & $p$ & 1999-2000 & 2010-2011 & $p$ \\
\hline Width of the beach (m) & $60(20)$ & $74(18)$ & 0.217 & $100(10)$ & $93(15)$ & 0.379 \\
\hline Intertidal width $(\mathrm{m})$ & $30(10)$ & $40(18)$ & 0.284 & $50(9)$ & $40(10)$ & 0.096 \\
\hline Sediment granulometry $(\mu \mathrm{m})$ & $291.15(20.61)$ & $319.56(30.56)$ & 0.442 & 761.78 (119.69) & $829.12(90.21)$ & 0.443 \\
\hline Sediment moisture (\%) & $3.24(1.22)$ & $7.47(6.68)$ & 0.061 & $2.64(0.95)$ & $4.55(4.26)$ & 0.178 \\
\hline Supralittoral & $2.53(1.44)$ & $2.17(1.37)$ & 0.529 & $2.08(1.30)$ & $1.36(1.02)$ & 0.128 \\
\hline Intertidal & $4.11(1.88)$ & $6.77(5.45)$ & 0.152 & $3.07(0.88)$ & $4.76(3.83)$ & 0.186 \\
\hline Organic matter content (\%) & $0.15(0.05)$ & $0.16(0.13)$ & 0.959 & $0.19(0.35)$ & $0.45(0.62)$ & 0.239 \\
\hline Supralittoral & $0.13(0.03)$ & $0.12(0.07)$ & 0.925 & $0.19(0.35)$ & $0.61(0.87)$ & 0.161 \\
\hline Intertidal & $0.15(0.04)$ & $0.14(0.14)$ & 0.962 & $0.21(0.38)$ & $0.29(0.13)$ & 0.443 \\
\hline
\end{tabular}


Cabedelo

(a)

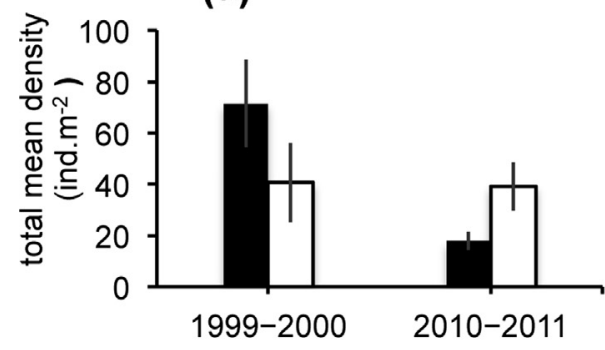

(b)

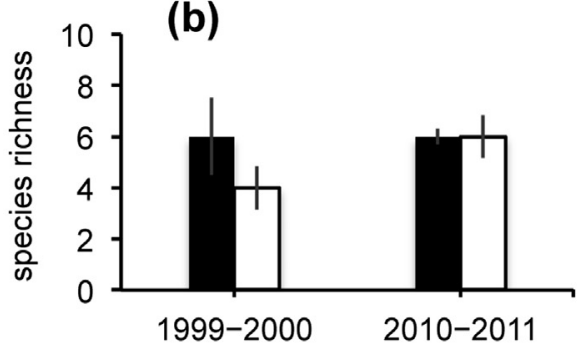

(c)

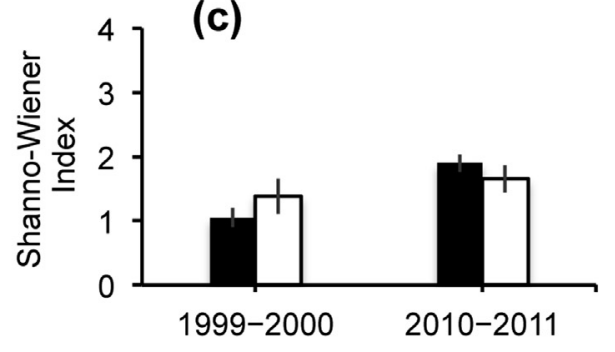

Quiaios

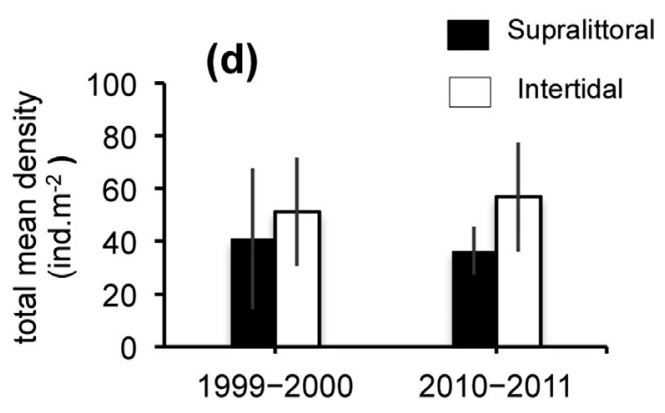

(e)

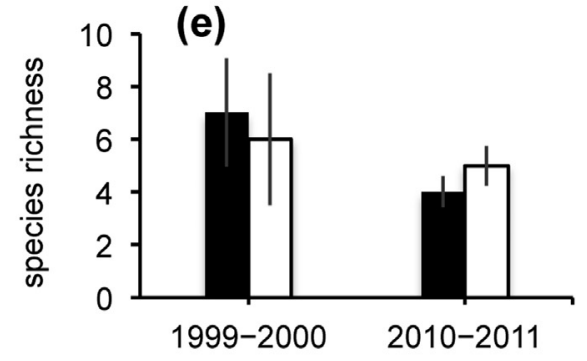

(f)

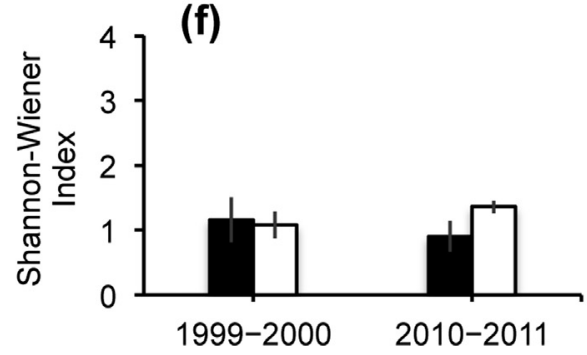

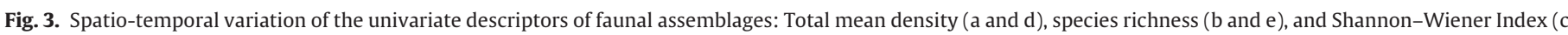
and f), for Cabedelo and Quiaios beaches among periods. Mean values and standard errors are presented for the zones (supralittoral and intertidal) of each beach.

structure of the macrofauna community was recorded for each beach. At Cabedelo beach, the most abundant species were $T$. saltator (54\%), T. europaeus (11\%) and T. brito (8\%), while at Quiaios the most abundant species were T. europaeus (67\%), followed by $T$. brito (20\%) and T. saltator (9\%). Still, this pattern was highly similar in both periods (see Appendix A).

\subsubsection{Univariate patterns}

Regarding species composition based on density data of macrofauna, at Cabedelo beach was recorded a decrease in the mean total density of macrofauna, in particular in the supralittoral zone (Fig. 3a, $72 \pm 17$ ind $\mathrm{m}^{2}$ in $1999-2000$ and $18 \pm 4$ ind $\mathrm{m}^{2}$ in 2010-2011). Nevertheless, these differences were not detected in the PERMANOVA outputs (Table $2, p$ (perm) $>0.05$ for all factors with interaction with time), where the mean total density of macrofauna, the number of taxa, and diversity (Shannon-Wiener Index) of both beaches did not register significant different temporal trajectories (interaction term Beach $\times$ Time: $p($ perm) $>0.05$ for these univariate descriptors, Table 2).

However, concerning the individual average density of two of the most abundant species (the talitrid T. saltator and the tylid T. europaeus), PERMANOVA tests showed a clear different temporal trajectory for each beach considered (Table 2 and Fig. 4), with a significant interaction term Beach $\times$ Time found for both species (Table 2, T. saltator $p($ perm) $=0.0046$, and $T$. europaeus $p($ perm $)=0.0053)$. The posterior pairwise comparisons for this significant interaction term showed that the temporal differences between 1999-2000 and 2010-2011 periods were only detected for these species at Cabedelo beach (pairwise test: T. saltator $p$ (perm $)=0.0132$, and $T$. europaeus $p($ perm $)=0.0109)$, with both species showing a clear decrease in their abundances between the two periods considered (Fig. 4a and b). On the other hand, at Quiaios beach no significant temporal variability was shown (pairwise comparisons for all terms $p$ (perm) >0.05) for both $T$. saltator and T. europaeus (Fig. $4 \mathrm{c}$ and d). The density of the other sympatric talitrid, $T$. brito, varied only between the zone of each beach and along the seasons (Table 2) but did not register a temporal variation among the periods for each beach (Table 2 , $B \times T$ interaction: $p$ (perm) $=0.2459$ ).

In terms of variation in the spatial scale, in the case of the talitrid $T$. saltator, the decrease in their abundances between the two periods at Cabedelo beach occurred in both supralittoral and intertidal zones of the beach (pairwise tests resulted $>0.05$ for all terms from the interaction term $Z(B) \times T$, Table 2). Additionally, PERMANOVA tests showed a borderline significant interaction in the term $S(Z$ $(B)) \times T$ (Table $2 p($ perm $)=0.05)$ for $T$. saltator, and the investigation of the pairwise comparisons showed a significant decrease in their density between 1999-2000 and 2010-2011 in the supralittoral zone of Cabedelo beach during the spring (Fig. 4a, and $p$ $(\mathrm{MC})=0.05$ ), and in the intertidal zone during the summer (Fig. $4 \mathrm{~b}$, $p(\mathrm{MC})=0.02$ ). A similar pattern was detected for $T$. europaeus, with a significant temporal decrease in their abundances being recorded in the supralittoral zone of Cabedelo beach during the springtime (pairwise test: $p(\mathrm{MC})=0.0036$ ). 
Table 2

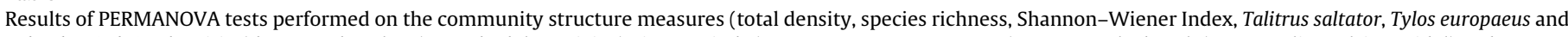

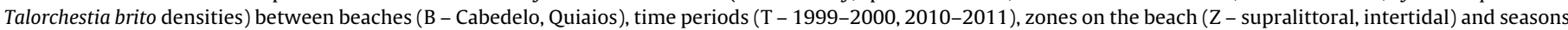
( $\mathrm{S}$ - spring, summer, autumn and winter).

\begin{tabular}{|c|c|c|c|c|c|c|c|c|c|c|c|c|c|}
\hline \multirow[t]{2}{*}{ Factor } & \multicolumn{3}{|c|}{ Total density } & \multicolumn{2}{|c|}{ Species richness } & \multicolumn{2}{|c|}{$\begin{array}{l}\text { Shannon-Wiener } \\
\text { Index }\end{array}$} & \multicolumn{2}{|c|}{ Talitrus saltator } & \multicolumn{2}{|c|}{ Tylos europaeus } & \multicolumn{2}{|c|}{ Talorchestia brito } \\
\hline & df & MS & $F$ & MS & $F$ & MS & $F$ & MS & $F$ & MS & $F$ & MS & $F$ \\
\hline$B$ & 1 & 0.74 & 0.04 & 0.23 & 0.41 & 2.03 & 4.91 & 59.29 & $5.94^{* * *}$ & 105.35 & $5.78^{* *}$ & 13.56 & 3.75 \\
\hline$T$ & 1 & 11.39 & 2.61 & 0.04 & 0.02 & 1.38 & 6.19 & 19.87 & $9.43^{* * *}$ & 7.57 & 2.52 & 4.21 & 3.91 \\
\hline$Z(B)$ & 2 & 0.92 & 0.04 & 0.06 & 0.11 & 0.11 & 0.28 & 12.79 & 1.28 & 3.02 & 0.17 & 16.48 & $4.56^{* *}$ \\
\hline$B \times T$ & 1 & 7.65 & 1.76 & 1.26 & 5.54 & 0.61 & 2.75 & 24.81 & $11.77^{* * *}$ & 4.99 & $1.66^{*}$ & 1.66 & 1.54 \\
\hline$S \times(Z(B))$ & 12 & 21.93 & $7.95^{* * *}$ & 0.58 & $2.42^{*}$ & 0.42 & 1.94 & 10.15 & $11.19 * * *$ & 18.55 & $12.31^{* * *}$ & 3.66 & $3.39^{* * *}$ \\
\hline$Z(B) \times T$ & 2 & 9.64 & 2.22 & 0.45 & 1.96 & 0.49 & 2.18 & 4.72 & $2.24^{*}$ & 1.59 & 0.53 & 4.05 & 3.76 \\
\hline$S(Z(B)) \times T$ & 12 & 4.38 & 1.59 & 0.23 & 0.95 & 0.22 & 1.03 & 2.13 & 2.35 & 3.02 & 2.01 & 1.08 & 0.99 \\
\hline Res & 20 & 2.76 & & 0.24 & & 0.21 & & 0.91 & & 1.51 & & 1.08 & \\
\hline Total & 51 & & & & & & & & & & & & \\
\hline
\end{tabular}

Bold values indicate significant results:

${ }^{*} p<0.05$.

*** $p<0.01$.

*** $p<0.001$.

In order to investigate the changes in the abundance of these two species between the two periods with the potential effects of the increasing human presence at both beaches, we performed a Pearson correlation between the density of $T$. saltator and $T$. europaeus and the number of tourists in the same period. For Cabedelo beach, a negative and significant correlation was found between these two variables ( $T$. saltator: $r=-0.879, p=0.004 ; T$. europaeus: $r=-0.49, p=0.05)$, while for Quiaios beach no significant correlation was detected for both species ( $T$. saltator: $r=0.399, p=0.199 ;$. . europaeus: $r=0.162, p=0.614$ ). Additionally, at Quiaios, no significant spatial or temporal differences over the studied period were found for all the univariate faunal descriptors (Table 2, pairwise comparisons for all terms: $p$ (perm) $>0.05$, Fig. $3 \mathrm{~d}-\mathrm{f}$ ). In this beach, the average value for the total density of macrofauna was highly similar for both periods $\left(46 \pm 5\right.$ ind $\mathrm{m}^{2}$ in 1999-2000 and 48 \pm 3 ind $\mathrm{m}^{2}$ during 2010-2011) and a similar pattern was observed for the species richness (Fig. 3e) and diversity (Fig. 3f).

\subsubsection{Multivariate patterns}

The multivariate analyses of the macrofaunal assemblages' structure presented the significant effect of time $(T)$, beach $(B)$ and zone of the beach considered $(Z(B))$ (Table 3 ). Additionally, the PERMANOVA tests revealed a significant Beach $\times$ Time interaction $(p($ perm $)=0.0077$, Table 3$)$, implying that the temporal trends in the macrofaunal communities' structure differed between the two beaches (Table 3 ). Analyses of pairwise comparisons on this interaction term confirmed the temporal stability of the community structure at Quiaios beach $(p($ perm $)=0.2903$, Table 3$)$, with significant differences in the community structure detected only at Cabedelo between 1999-2000 and 2010-2011 $(p($ perm $)=0.0028$, Table 3 and Fig. 5). At this beach, the temporal variation in the macrofauna structure among periods was also recorded in both supralittoral $(p($ perm $)=0.0335)$ and intertidal $(p($ perm $)=0.0347)$ zones of the beach (Table 3, Fig. 5). The most important taxa contributing to dissimilarities among periods at Cabedelo (SIMPER analysis) were the amphipod T. saltator and the isopod T. europaeus.

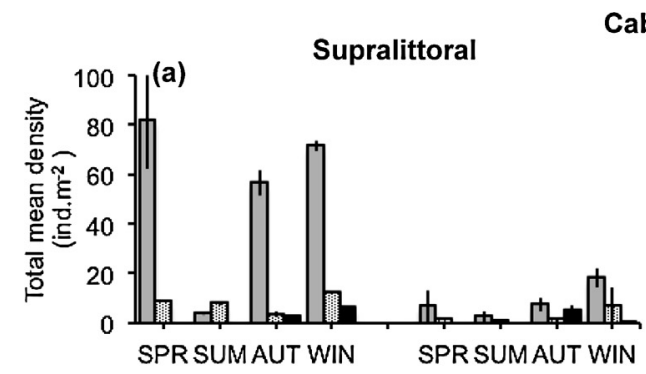

Cabedelo

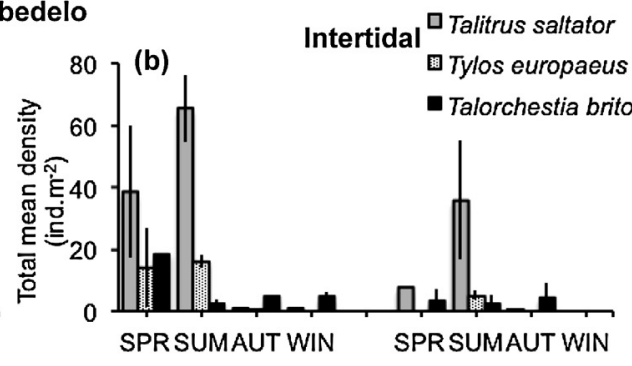

Quiaios
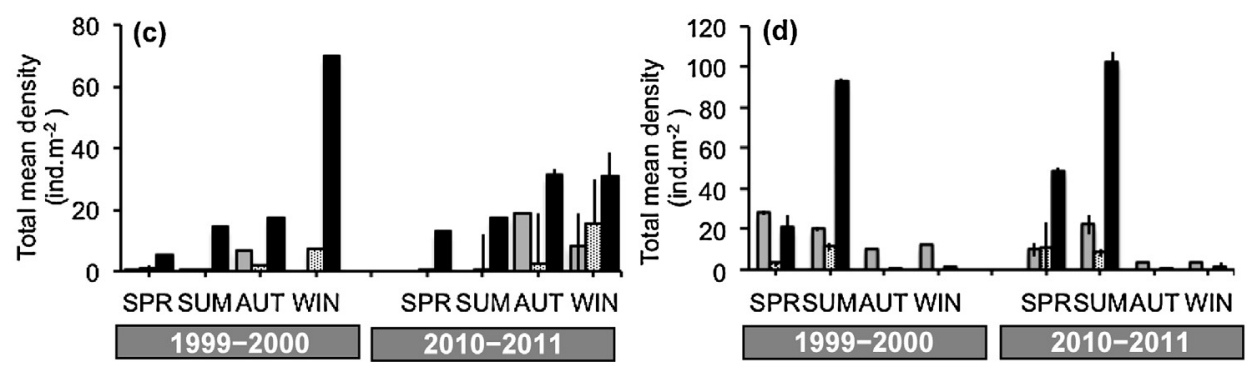

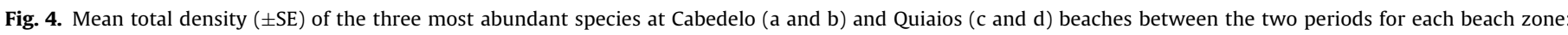
supralittoral (a and c) and intertidal (b and d). SPR, spring; SUM, summer; AUT, autumn and WIN, winter. 
Table 3

PERMANOVA results and pairwise comparisons performed to compare macrofaunal assemblages between beaches (B - Cabedelo, Quiaios), periods (T1: 1999-2000, T2: 2010-2011), zones on the beach (Z: Sup - supralittoral, Int - intertidal) and seasons ( $\mathrm{S}$ - spring, summer, autumn and winter). Bold values correspond to significant results.

\begin{tabular}{|c|c|c|c|c|}
\hline Factor & df & MS & Pseudo-F & $p($ Perm $)$ \\
\hline$B$ & 1 & 12,533 & 47.12 & 0.0004 \\
\hline$T$ & 1 & 5373.5 & 8.59 & 0.0006 \\
\hline$Z(B)$ & 2 & 8378.6 & 3.15 & 0.0083 \\
\hline$B \times T$ & 1 & 2624.3 & 4.19 & 0.0077 \\
\hline$S \times(Z(B))$ & 12 & 2697.3 & 4.28 & 0.0001 \\
\hline$Z(B) \times T$ & 2 & 2223 & 3.55 & 0.0039 \\
\hline$S(Z(B)) \times T$ & 12 & 625.9 & 0.99 & 0.4962 \\
\hline Res & 20 & 630.6 & & \\
\hline Pairwise test & & Condition & & $p(\mathrm{MC})$ \\
\hline \multirow[t]{2}{*}{$B \times T$} & & \multicolumn{2}{|c|}{ Cabedelo $\times$ T1 vs. T2 } & 0.0028 \\
\hline & & \multicolumn{2}{|c|}{ Quiaios $\times$ T1 vs. T2 } & 0.2903 \\
\hline \multirow[t]{4}{*}{$Z(B) \times T$} & & \multicolumn{2}{|c|}{ Cabedelo $\times$ T1 vs. T2 $\times$ Sup } & 0.0335 \\
\hline & & \multicolumn{2}{|c|}{ Cabedelo $\times$ T1 vs. T2 $\times$ Int } & 0.0347 \\
\hline & & \multicolumn{2}{|c|}{ Quiaios $\times$ T1 vs. T2 $\times$ Sup } & 0.7466 \\
\hline & & \multicolumn{2}{|c|}{ Quiaios $\times \mathrm{T} 1$ vs. $\mathrm{T} 2 \times$ Int } & 0.0765 \\
\hline
\end{tabular}

These two species were responsible by $46 \%$ of the $63 \%$ dissimilarities found between periods in this beach.

Together, these results reflect the univariate analyses (mean total density for two of the most abundant species, $T$. saltator and T. europaeus) by suggesting a change in the abundances of these species at Cabedelo beach observed over the 10-years interval considered.

\section{Discussion}

The current work allowed us to compare the macrofaunal assemblages of rural (Quiaios) and urban (Cabedelo) beaches on the Atlantic coast of mainland Portugal (central region), that have received different intensities of human pressures, and also to compare the information recorded in 2010-2011 with a former study carried out on the same beaches in 1999-2000 (Gonçalves et al., 2009).

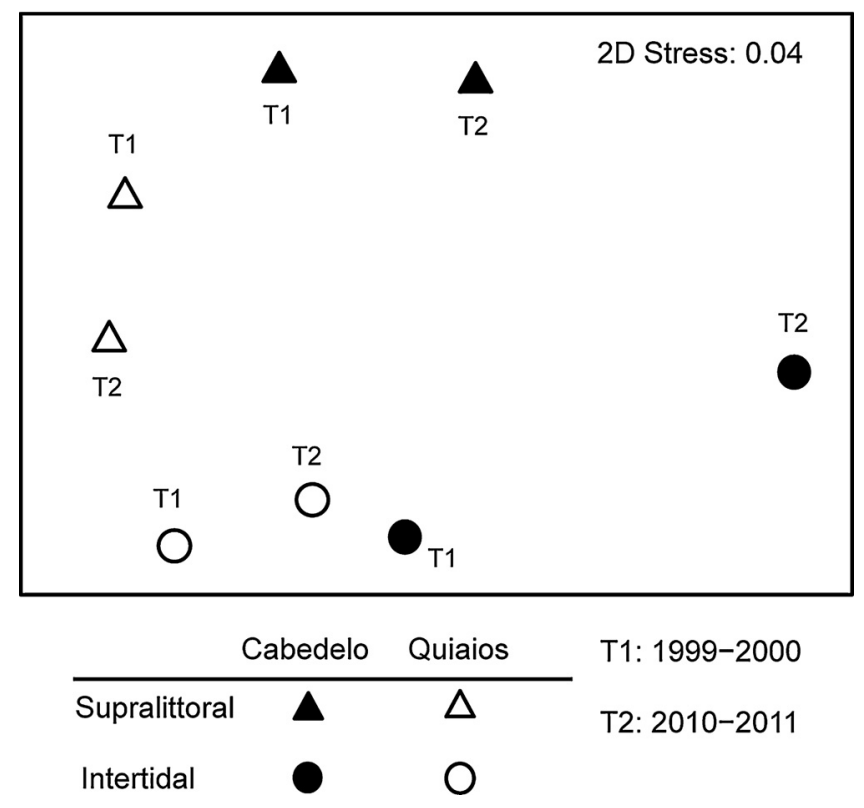

Fig. 5. Ordination (NMDS) of centroids derived from Principal Coordinate Analysis (PCO) for the combination of factors: Beach (Cabedelo vs. Quiaios) and zones of the beach (supralittoral vs. intertidal) for the two studied periods.
In this study, the analyses on both univariate and multivariate data regarding the composition and structure of the macrofaunal assemblages revealed a different temporal trajectory for Cabedelo and Quiaios beaches. At Quiaios beach, the mean total density of the macrofauna sampled, the number of species and diversity (Shannon-Wiener Index), and the overall structure of the macrofauna was highly similar and stable for both periods considered, which appears to reflect the steady environmental conditions recorded in this beach (Table 1 ). This trend was also reported for the most abundant species (T. europaeus, $T$. brito and T. saltator), which is fully coherent with the fact that in this beach no major physical changes (e.g. coastal engineering) or intensive increase in the recreational activities were detected between the periods considered. Therefore, the undisturbed character of this beach described in 1999-2000 by Gonçalves et al. (2009) seems to persist in the recent period of 2010-2011.

In contrast, a different scenario was described for the urban beach of Cabedelo. Our study identified major temporal significant declines in the abundance of two invertebrate species, the amphipod $T$. saltator and the isopod T. europaeus, two key species in these sandy beaches (Gonçalves et al., 2009, 2013). Multivariate techniques (SIMPER) also discriminate these species as responsible for the main differences in the structure of the macrofaunal assemblages between the two periods at this beach. We assert that these temporal changes in the macrofauna observed only at the urban beach (Cabedelo) are most likely attributed to the potential effect of the increased human pressures recorded, since the beach morphodynamic conditions were highly similar between the two periods considered (Table 1 ). In addition, the lower densities of the talitrid T. saltator in 2010-2011 at Cabedelo beach when compared with the first period analysed, were recorded in both supralittoral and intertidal zones of the beach. Still, these differences were driven primarily by shifts in the relative densities of this talitrid in the supralittoral zone of the beach during the spring (also recorded for T. europaeus), and in the intertidal zone during the summer, which is eventually reflected by the highest intensity of human use of beaches in the hottest and more touristic seasons, and by the different distribution of these species along the shore, in order to avoid the dry conditions that occur in the supralittoral zone of the beach during the summer.

In this study, even though the increase in the number of tourists occupying the central region was used as a measure (proxy) of the quantification of human use of beaches, the negative correlation found with the number of $T$. saltator and T. europaeus can sustain the hypothesis of a potential impact that stems from recreational use of the beach during the touristic seasons (spring-summer). These results also support our prediction that the cumulative disturbances on the upper zone of the beach due to construction of facilities, shoreline development and grooming over time, can also be potentially associated with the declines of abundance of these species that rely mainly on the supralittoral zone of the beach (e.g. Bouslama et al., 2009; Colombini et al., 2002; Lastra et al., 2010). For instance, the presence of breakwaters per se can limit the physical communication with adjacent beaches and may consequently not allow the connectivity of populations of these and other upper beach species, which may in turn compromise the viability of these macroinvertebrates on this beach over time. Despite exposed sandy beaches are considered resilient environments, intensive human modifications of the coastal zone can severely limit the ability of beaches to adjust to changes in the shoreline stability and limit its flexibility (Nordstrom et al., 2000). Still, supralittoral species, such as talitrids and tylids are known to be well adapted to the highly dynamic and variable conditions acting on beaches but their limited dispersal and habitat dependencies make them also sensitive indicators of beach disturbances (Defeo and Gomez, 2005; McLachlan and Brown, 2006). For instance, some studies illustrated 
an overall remarkable negative impact on supralittoral species as a result of human beach use (e.g. Fanini et al., 2005; Veloso et al., 2006, 2008; Ugolini et al., 2008) and shoreline modifications such as the construction of seawalls or beach nourishment actions (e.g. Bessa et al., 2013; Dugan and Hubbard, 2006; Fanini et al., 2009). Furthermore, recreational beaches are known to be affected by regular mechanical cleaning (in particular in the supralittoral zone), which is responsible for a considerable reduction of the organic matter available for the fauna on the beach, but also for the disturbance of the sediment, leading to the absence of suitable niches to support these communities, creating a resource-limited environment (McLachlan and Brown, 2006). Given the multiple key roles that talitrids and tylids play in temperate beach ecosystems (e.g. Colombini et al., 2003; Gonçalves and Marques, 2011; Lastra et al., 2010), minimising the human impacts to the beach fauna is crucial to maintain the functional integrity of these ecosystems. In this sense, the reduction of important trophic groups at Cabedelo beach may produce negative consequences on the ecosystems energy balance.

Notwithstanding, the assessment of these changes in the beach system as a result of long-term human pressures is here only considered potential, because our estimates rely on an approximate quantification of the human use of beaches and on information about the physical constructions on the beach, and these potential cumulative human pressures can be reduced or increased by natural variability and/or other stochastic events.

We suggest that further long-term monitoring programmes focus on identifying the nature of changes may be the next challenge for sandy beach ecologists in particular on the European Atlantic coast that is being increasingly disturbed (Veloso-Gomes and Taveira-Pinto, 2003; Coelho et al., 2009). Herein, sandy beach ecologists have been enhancing the need to protect and restore the ecological structures, functions and values of beaches. However, the efficacy of any active management in this regard in the Portuguese coast is hindered by the lack of baseline information about potential impacts acting on the ecosystems and the ecological responses of beach environment and biota. Since the ecological relevance of exposed sandy beaches is not considered in the priority of these actions, we think that this study can be a first attempt to provide valuable information about the effects of the increase of human pressures that can potentially be translated into ecological impacts and jeopardise the entire ecosystem and the goods and services that humans directly derive from it (Defeo et al., 2009).

Globally, it is generally accepted that beach recreation is the major service provided by ocean beaches to society. However, as Jaramillo (2012) said "sandy beaches are not only important for recreation but also need conservation".

\section{Acknowledgments}

This research was supported by FCT (Fundação para a Ciência e Tecnologia) through a PhD Grant awarded to Ana Filipa Bessa (SFRH/BD/64929/2009), and by the project PEstC/MAR/UI0284/2011, funded by FCT. We wish to give our special thanks to all who assisted us in the fieldwork.

\section{Appendix A.}

See Table A1.

Table A1

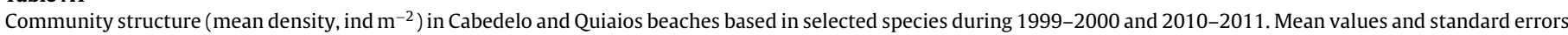
are presented for the zones (supralittoral and intertidal) of each studied beach.

\begin{tabular}{|c|c|c|c|c|}
\hline & \multicolumn{2}{|l|}{ Cabedelo } & \multicolumn{2}{|l|}{ Quiaios } \\
\hline & 1999-2000 & 2010-2011 & 1999-2000 & 2010-2011 \\
\hline \multicolumn{5}{|l|}{ Supralittoral } \\
\hline \multicolumn{5}{|l|}{ Amphipoda } \\
\hline Talitrus saltator & $59.3(16.18)$ & $8.96(2.65)$ & $2.33(1.34)$ & $4.59(3.09)$ \\
\hline Talorchestia brito & $1.81(1.26)$ & $1.35(0.93)$ & $1.5(1.29)$ & $6.78(3.27)$ \\
\hline Talorchestia desayesii & - & $0.14(0.09)$ & - & $0.52(0.52)$ \\
\hline Pontocrates arenarius & - & - & - & - \\
\hline Haustorius arenarius & - & $0.10(0.10)$ & - & - \\
\hline \multicolumn{5}{|l|}{ Mysidacea } \\
\hline Gastrosaccus sanctus & - & - & - & $0.10(0.10)$ \\
\hline \multicolumn{5}{|l|}{ Isopoda } \\
\hline Tylos europaeus & $8.38(1.41)$ & $2.81(1.64)$ & $35.34(24.85)$ & $23.13(5.54)$ \\
\hline Eurydice pulchra & $0.15(0.09)$ & $0.21(0.14)$ & - & $0.10(0.10)$ \\
\hline \multicolumn{5}{|l|}{ Insecta } \\
\hline Coleoptera & $0.56(0.23)$ & $1.04(0.41)$ & $0.48(0.21)$ & $0.10(0.10)$ \\
\hline Mecoptera & - & - & $0.50(0.01)$ & $1.15(0.47)$ \\
\hline Hemiptera & $0.43(0.06)$ & $1.22(0.41)$ & $0.30(0.01)$ & - \\
\hline Hymenoptera & $0.27(0.03)$ & $0.50(0.06)$ & $0.20(0.01)$ & - \\
\hline \multicolumn{5}{|l|}{ Intertidal } \\
\hline \multicolumn{5}{|l|}{ Amphipoda } \\
\hline Talitrus saltator & $18.01(12.21)$ & $6.04(2.43)$ & $3.66(2.13)$ & $4.93(2.23)$ \\
\hline Talorchestia brito & $9.92(4.55)$ & $2.64(1.34$ & $19.73(4.31)$ & $9.86(3.10)$ \\
\hline Talorchestia desayesii & - & $0.20(0.14)$ & - & $0.90(0.53)$ \\
\hline Pontocrates arenarius & $0.43(0.42)$ & $3.82(3.21)$ & - & - \\
\hline Haustorius arenarius & - & $1.11(0.62)$ & - & - \\
\hline \multicolumn{5}{|l|}{ Mysidacea } \\
\hline Gastrosaccus sanctus & $2.11(2.11)$ & $5(2.59)$ & - & $2.08(1.42)$ \\
\hline \multicolumn{5}{|l|}{ Isopoda } \\
\hline Tylos europaeus & $8.98(5.32)$ & $1.31(0.92)$ & $27.38(17.04)$ & $38.26(16.04)$ \\
\hline Eurydice pulchra & $1.18(1.07)$ & $17.57(8.35)$ & - & $0.14(0.09)$ \\
\hline \multicolumn{5}{|l|}{ Insecta } \\
\hline Coleoptera & $0.14(0.02$ & $0.13(0.09)$ & $1.04(0.41)$ & $0.06(0.19)$ \\
\hline Mecoptera & $0.27(0.03)$ & $0.13(0.09)$ & - & - \\
\hline Hemiptera & - & $1.32(0.39)$ & $0.34(0.34)$ & $0.55(0.33)$ \\
\hline Hymenoptera & - & - & - & - \\
\hline
\end{tabular}




\section{References}

Anderson, M.J., 2001. A new method for non-parametric multivariate analysis of variance. Austral Ecol. 26, 32-46.

Bessa, F., Cunha, D., Gonçalves, S.C., Marques, J.C., 2013. Sandy beach macrofaunal assemblages as indicators of anthropogenic impacts on coastal dunes. Ecol. Ind. 30, 196-204.

Bouslama, M.F., ElGtari, M., Charfi-Cheikhrouha, F., 2009. Impact of environmental factors on zonation, abundance, and other biological parameters of two Tunisian populations of Talitrus saltator (Amphipoda, Talitridae). Crustaceana $82,141-157$

Brown, A.C., McLachlan, A., 2002. Sandy shore ecosystems and the threats facing them: some predictions for the year 2025. Environ. Conserv. 29, 62-77.

Coelho, C., Silva, R., Veloso-Gomes, F., Taveira-Pinto, F., 2009. Potential effects of climate change on northwest Portuguese coastal zones. ICES J. Mar. Sci. 66, 1497-1507.

Colombini, I., Aloia, A., Bouslama, M.F., ElGtari, M., Fallaci, Ronconi, L., Scapini, F., Chelazzi, L., 2002. Small-scale spatial and seasonal differences in the distribution of beach arthropods on the northwestern Tunisian coast. Are species evenly distributed along the shore? Mar. Biol. 140, 1001-1012.

Colombini, I., Fallaci, M., Milanesi, F., Scapini, F., Chelazzi, L., 2003. Comparative diversity analysis in sandy littoral ecosystems of the western Mediterranean. Estuarine Coastal Shelf Sci. 58, 93-104.

Cunha, P.P., Dinis, J., 1998. A erosão nas praias do Cabo Mondego à Figueira da Foz (Portugal centro-oeste), de 1995 a 1998. Territorium, Editora Minerva, Coimbra, Portugal.

Cunha, P.P., Dinis, J., 2002. Sedimentary dynamics of the Mondego estuary. In: Pardal, M.A., Marques, J.C., Graça, M.A.S. (Eds.), Aquatic Ecology of the Mondego River Basin. Global Importance of Local Experience. Imprensa da Universidade, Univ. Coimbra, Coimbra.

Defeo, O., Gomez, J., 2005. Morphodynamics and habitat safety in sandy beaches: life-history adaptations in a supralittoral amphipod. Mar. Ecol. Prog. Ser. 293, $143-153$.

Defeo, O., McLachlan, A., 2005. Patterns, processes and regulatory mechanisms in sandy beach macrofauna: a multi-scale analysis. Mar. Ecol. Prog. Ser. 295, $1-20$.

Defeo, O., McLachlan, A., Schoeman, D.S., Schlacher, T.A., Dugan, J., Jones, A., Lastra, M., Scapini, F., 2009. Threats to sandy beach ecosystems: a review. Estuarine Coastal Shelf Sci. 81, 1-12.

Dugan, J.E., Defeo, O., Jaramillo, E., Jones, A.R., Lastra, M., Nel, R., Peterson, C.H., Scapini, F., Schlacher, T.A., Schoeman, D.S., 2010. Give beach ecosystems their day in the sun. Science 329, 1146

Dugan, J.E., Hubbard, D.M., 2006. Ecological responses to coastal armoring on exposed sandy beaches. Shore Beach 74, 10-16.

Dugan, J.E., Hubbard, D.M., Rodil, F., Revell, D.L., Schroeter, S., 2008. Ecological effects of coastal armoring on sandy beaches. Mar. Ecol. 29, 160-170.

Eurosion, 2004. Living with coastal erosion in Europe: sediment and space for sustainability. In: Part II e Maps and Statistics.

Fanini, L., Cantarino, C.M., Scapini, F., 2005. Relationships between the dynamics of two Talitrus saltator populations and the impacts of activities linked to tourism. Oceanologia 47, 93-112.

Fanini, L., Marchetti, G.M., Scapini, F., Defeo, O., 2009. Effects of beach nourishment and groynes building on population and community descriptors of mobile arthropodofauna. Ecol. Ind. 9, 167-178.

GHK, 2006. Evaluation on environment and risk prevention under structural and cohesion funds for the period 2007-2013: national evaluation report for Portugal. In: Report for the EC Directorate General Regional Policy, GHK in Association With Ecolas. IEEP and Cambridge Econometrics, Brussels/ London.

Gonçalves, S.C., Anastácio, P.M., Marques, J.C., 2013. Talitrid and Tylid crustaceans bioecology as a tool to monitor and assess sandy beaches' ecological quality condition. Ecol. Ind. 29, 549-557.

Gonçalves, S.C., Anastácio, P.M., Pardal, M.A., Cardoso, P.G., Ferreira, S.M., Marques, J.C., 2009. Sandy beach macrofaunal communities on the western coast of Portugal - is there a steady structure under similar exposed conditions? Estuarine Coastal Shelf Sci. 81, 555-568.

Gonçalves, S.C., Marques, J.C., 2011. The effects of season and wrack subsidy on the community functioning of exposed sandy beaches. Estuarine Coastal Shelf Sci. 95, 165-177.

Halpern, B.S., McLeod, K.L., Rosenberg, A.A., Crowder, L.B., 2008. Managing for cumulative impacts in ecosystem-based management through ocean zoning. Ocean Coast. Manage. 51, 203-211.
Jaramillo, E., 2012. Ecological implications of extreme events on exposed sandy beaches: insights from the 2010 Chilean earthquake. In: VIth International Sandy Beach Symposium. Public presentation, South Africa, 26 June.

Jones, A.R., Murray, A., Lasiak, T.A., Marsh, R.E., 2008. The effects of beach nourishment on the sandy-beach amphipod Exoediceros fossor: impact and recovery in Botany Bay, New South Wales, Australia. Mar. Ecol. 29, 28-36.

Lastra, M., Schlacher, T.A., Olabarria, C., 2010. Niche segregation in sandy beach animals: an analysis with surface-active peracarid crustaceans on the Atlantic coast of Spain. Mar. Biol. 157, 613-625.

Marques, J.C., Gonçalves, S.C., Pardal, M.A., Chelazzi, L., Colombini, I., Fallaci, M., Bouslama, M.F., Gtari El, M., Charfi-Cheikhrouha, F., Scapini, F., 2003. Comparison of Talitrus saltator (Amphipoda Talitridae) biology, dynamics, and secondary production in Atlantic (Portugal) and Mediterranean (Italy and Tunisia) populations. Estuarine Coastal Shelf Sci. 58, 127-148.

McLachlan, A., 1980. The definition of sandy beaches in relation to exposure: a simple rating system. S. Afr. J. Sci. 76, 137-138.

McLachlan, A., Brown, A., 2006. The Ecology of Sandy Shores, 2nd ed. Academic Press, New York.

Millenium Ecosystem Assessment, 2005. Ecosystems and Human Well-being: Synthesis Report. World Resources Institute, Washington, DC.

Nordstrom, K., Lampe, R., Vandemark, L., 2000. Reestablishing naturally functioning dunes on developed coasts. Environ. Manage. 25, 37-51.

Santos, F., Seabra, A.J., Carmo, J.A., 1991. Estudo da agitação marítima. In: Relatório final do projeto de investigação - "Lançamento de bases para o estudo integrado do estuário do Mondego. Univ. Coimbra, pp. 153.

Schlacher, T.A., de Jager, R., Nielsen, T., 2011. Vegetation and ghost crabs in coastal dunes as indicators of putative stressors from tourism. Ecol. Ind. 11, 284-294.

Schlacher, T.A., Dugan, J., Schoeman, D.S., Lastra, M., Jones, A., Scapini, F., McLachlan, A., Defeo, O., 2007. Sandy beaches at the brink. Divers. Distrib. 13, 556-560.

Schlacher, T.A., Lucrezi, S., 2010. Compression of home ranges in ghost crabs on sandy beaches impacted by vehicle traffic. Mar. Biol. 157, 2467-2474.

Schlacher, T.A., Noriega, R., Jones, A., Dye, T., 2012. The effects of beach nourishment on benthic invertebrates in eastern Australia: Impacts and variable recovery. Sci. Total Environ. 435-436, 411-417.

Schlacher, T.A., Richardson, D., McLean, I., 2008a. Impacts of Off-Road Vehicles (ORVs) on macrobenthic assemblages on sandy beaches. Environ. Manage. 41 878-892.

Schlacher, T.A., Schoeman, D.S., Dugan, J., Lastra, M., Jones, A., Scapini, F., McLachlan, A., 2008b. Sandy beach ecosystems: key features, sampling issues, management challenges and climate change impacts. Mar. Ecol. 29, 70-90.

Schlacher, T.A., Schoeman, D.S., Lastra, M., Jones, A., Dugan, J., Scapini, F., McLachlan, A., 2006. Neglected ecosystems bear the brunt of change. Ethol. Ecol. Evol. 18, 349-351.

Schlacher, T.A., Thompson, L., 2012. Beach recreation impacts benthic invertebrates on ocean-exposed sandy shores. Biol. Conserv. 147, 123-132.

Sheppard, N., Pitt, K.A., Schlacher, T.A., 2009. Sub-lethal effects of off-road vehicles (ORVs) on surf clams on sandy beaches. J. Exp. Mar. Biol. Ecol. 380, 113-118.

Ugolini, A., Ungherese, G., Somigli, S., Galanti, G., Baroni, D., Borghini, F., Cipriani, N., Nebbiai, M., Passaponti, M., Focardi, S., 2008. The amphipod Talitrus saltator as a bioindicator of human trampling on sandy beaches. Mar. Environ. Res. 65, 349-357.

Underwood, A.J., 1992. Beyond BACI: the detection of environmental impacts on populations in the real, but variable, world. J. Exp. Mar. Biol. Ecol. 161, 145-178.

Underwood, A.J., 1993. The mechanisms of spatially replicated sampling programmes to detect environmental impacts in a variable world. Austr. J. Ecol. 18, 99-116.

Veloso-Gomes, F., Taveira-Pinto, F., 2003. Portuguese coastal zones and the new coastal management plans. J. Coast. Conserv. 9, 25-34.

Veloso, V.G., Neves, G., Lozano, M., Perez Hurtado, A., Gago, C.G., Hortas, F., Garcia Garcia, F., 2008. Responses of talitrid amphipods to a gradient of recreational pressure caused by beach urbanization. Mar. Ecol. 29, 126-133.

Veloso, V.G., Silva, E.S., Caetano, C.H.S., Cardoso, R.S., 2006. Comparison between the macroinfauna of urbanized and protected beaches in Rio de Janeiro State, Brazil. Biol. Conserv. 127, 510-515.

Walker, S.J., Schlacher, T.A., 2011. Impact of a pulse human disturbance experiment on macrofaunal assemblages on an Australian sandy beach. J. Coast. Res. 275, 184-192.

Walker, S.W., Schlacher, T.A., Thompson, L.M.C., 2008. Habitat modification in a dynamic environment: the influence of a small artificial groyne on macrofaunal assemblages of a sandy beach. Estuarine Coastal Shelf Sci. 79, 24-34.

Wentworth, C., 1922. A scale of grade and class terms for clastic sediments. J. Geol. 922, 377-392. 